\title{
ARTICLE
}

Received 30 Nov 2015 | Accepted 18 Apr 2016 | Published 24 May 2016

DOI: $10.1057 /$ palcomms.2016.22

OPEN

\section{Exploring the pastiche hegemony of men}

\author{
Christopher R Matthews ${ }^{1}$
}

\begin{abstract}
In this article I explore the continued hegemony of certain men. I use interview extracts to help think through the notion of pastiche hegemony as a means of understanding how men, and narratives about them, have changed, but unequal power relations persist. In particular, I explore this process within men's understandings of how they were able to gain and maintain influence and power at work. Through their reflexive reading of the changing shape of late modern Western society, these men believed they were able to craft selves and employ social scripts to produce social influence and power in situational and contingent forms. I argue that it is within this interactional process that the increasingly undermined ideological and material legacy of patriarchy might still be reified. As such, while there is clear evidence highlighting the undermining of men's ability to assume power, within this article I theoretically unpack how certain men might be able to produce a localized, pastiche hegemony. This article is published as part of a thematic collection on gender studies.
\end{abstract}

\footnotetext{
${ }^{1}$ University of Brighton, School of Sport and Service Management, Eastbourne, UK Correspondence: (e-mail: dr.christopher.r.matthews@gmail.com)
} 
The problem shifts: men can change in some respects, without apparently undermining the power relations of gender. (Segal, 1993: 626)

n 1993 Lynne Segal captured the crux of this article; that men change and while some of those changes appear to align with progressive shifts towards gender, sex and sexuality equality, they still dominate society in a variety of ways. To understand this re-production of the "hegemony of men" (Hearn, 2004) I will argue that we need a theoretical account that can attend to the material, ideological and interpersonal dimensions of power. Such a conceptual framing should handle the tension between on the one hand, social shifts towards equality, which appear to undermine patriarchy, and on the other, the ways in which certain men can gain and maintain power within such changing social patterns.

In particular, I explore the potential for men to produce power through their ability to reflexively perform social scripts and craft different versions of self at appropriate times. This is achieved by developing Atkinson's (2011) understanding of how we can conceptualize men's agency in late modernity. In so doing, the notion of pastiche hegemony, whereby men gain and maintain social influence and power through the presentation of self in a contingent, situationally specific and contextual manner, is broadened to include a more explicit focus upon how men orientate themselves to social structures that constrain and enable this process. To provide some context for the empirical focus of this study and to highlight the need to reconsider the conceptualization of men's power, I will briefly discuss literature that explores, and offers some explanation for, inequality between the sexes at work.

\section{Inequality in work and organizations}

While classic texts within the sociology of work focused on the lives of men (Whyte, 1956; Dalton, 1959; Willis, 1977), it is more recent works that have explicitly focused on men as a gendered category rather than a normative standard (Cockburn, 1983; Walby, 1986; Collinson, 1988, 1992; Reskin, 1988; Morgan, 1992; Witz, 1992; DeCoster et al., 1999). This shift in focus has marked out in sharp relief how "most organizations are saturated with masculine values" (Burton, 1991: 3). The development of critical readings of the "breadwinner" role, sexism, sexual harassment, the marginalization of un-paid work and full-time lifelong employment has done much to undo the often-takenfor-granted power chances that are embedded in a variety of workplaces (Olson and Becker, 1983; Reskin, 1988; Adkins, 1995; DeCoster et al., 1999; Goldin and Rouse, 2000; Gorman, 2005; Ridgeway and England, 2007; Avery et al., 2008). And as Reskin (2000: 320) argues, "we need to move beyond demonstrating that employment discrimination exists, and investigate why it persists in work organizations".

Acker's (1990) contention that such discrimination continues due to the gendered landscape of work organizations has been evidenced in a large body of research. Here, divisions of labour, and representations of "appropriate" male and female work to reinforce such fault lines, are intertwined with day-to-day microsociological interactions between colleagues (Acker, 1990; Ridgeway and England, 2007). A crucial narrative in this process is that of the "ideal worker", which is often characterized by rationality and the ability to make personal sacrifices. More often than not, it is men who are considered to match up most closely with such notions (Collinson and Hearn, 1996; Prokos and Padavic, 2002; Ridgeway and England, 2007). Within these gendered stories, women often occupy a lesser position in that they are thought to lack rationality and are constrained, usually by motherhood, to be less committed to work (Adkins, 1995; Benard and Correll, 2010; Kelly et al., 2010). Rosabeth Moss Kanter neatly captured this process in 1975 arguing that:

A 'masculine ethic' of rationality and reason can be identified in the early images of managers. This 'masculine ethic' elevates the traits assumed to belong to men with educational advantages to necessities for effective organizations: a toughminded approach to problems; analytic abilities to abstract and plan; a capacity to set aside personal, emotional considerations in the interests of task accomplishment; a cognitive superiority in problem-solving and decision making. (Moss Kanter, 1975: 43, cited in Acker, 1990)

It is then reasonable to suggest that the symbolic connection between men and traditional paid work has been a central factor in men's social power, and historical and contemporary patterns of patriarchy.

Yet, shifts and changes to the structure of global and local economies associated with late modernity have undercut the stability of the social ordering of work, for as Bauman argues, organizations and careers are increasingly characterized by fluidity:

Not only have jobs-for-life disappeared, but trades and professions ... have acquired the confusing habit of appearing from nowhere and vanishing without notice ... and to rub salt into the wound the demand for the skills needed to practice such professions seldom lasts as long as the time needed to acquire them. (Bauman, 1996: 24)

Brody and Rubin (2011) point to this process when they argue that within the contemporary world of work, achievement is likely to be linked to one's ability to flexibly adapt to restructuring and technological changes. An understanding of the importance of this reordering in terms of gendered inequality can be found in Williams et al.'s (2012) reworking of Acker's thesis for application within the "new economy". For them, apparently gender-neutral shifts in the bureaucratic logic of organizations are played out in a manner that enables men, in various ways, to continue to gain advantage over women. Earlier evidence demonstrates that persistent patterns of gender inequality at work are reproduced in new forms as industrialization and technologization produce shifts in the manner that Western societies are organized (Cockburn, 1983; Savage, 1987; Strober and Arnold, 1987).

It appears that while well-trodden pathways towards dominance at work have been undermined in crucial ways, certain men can still redeploy and reinvent social power in a contingent and situated manner and social inequality can be recast and reconfirmed (McDowell, 1997; Hall et al., 2007; Williams et al., 2012; Brumley, 2014). As such, while the majority of discrimination in employment and education has become illegal (Burstein, 1989) and women have entered workplaces previously dominated by men (Blau et al., 2006), England (2010) argues that this gender "revolution" is uneven and stalled. And when taken together, I argue that this research demonstrates that while the takenfor-granted domination of paid work by men, a clear pillar of patriarchy, has been undermined, inequality still persists in a more complex and nuanced guise. This is evidence of changes to late modern Western society that lead Atkinson (2011; also see Matthews, 2014) to explore how we can theorize the recreation of men's power within a pastiche arrangement of social interactions and performances. 


\section{Pastiche hegemony and men's power}

In following Fraser (1989) and historically locating the notion of patriarchy it is possible to see that contemporary patterns of Western society, although marked by unequal power chances between the sexes and reinforced by discourses about gender, certainly do not match previous incarnations of men's power whereby the "rule of the father" was cast in religious and legal dogma (Walby, 1986; Hearn, 1992; Witz, 1992; MacInnes, 1998). Indeed, MacInnes (1998: 7) argues that the taken-for-granted nature of patriarchy has been fundamentally challenged, he suggests that "what we face in modern societies is no longer patriarchy itself, but its material and ideological legacy which in turn is systematically undermined by the key social relations of modernity". If this is the case, we need a theoretical conception of men's power that can help us gain conceptual purchase on the empirical manner in which this legacy might still be activated within late modernity.

Atkinson's $(2011,41)$ conception of men's power as existing in a reflexive arrangement of cultural scripts offers a good start point from which to explore this process. For him, power in late modernity is based:

... on being able to frame one's (masculine) identity in a chameleonlike way, and to embrace, incorporate, and reorder all identities that are struggling for cultural legitimacy. Such men realize that aligning one's sense of performed masculinity, for example, with insurgent gendered, racialized, working class, and other heretofore marginalised identities and related physical practices can make one appear as culturally progressive, cool, sensitive, moral, genuine, correct, or liberal in one context or another; each of these becomes techniques for achieving power in a liquid modern, reflexive identity-based society.

In this way, it is possible to understand that power is then produced at the intersection of multiple cultural and interpersonal processes, and that, while men and narratives about them might change, such changes bring with them new power chances.

Borrowing Jameson's (1991) understanding of postmodern identifications as connected to a pastiche arrangement of cultural narratives, whereby renditions of social scripts are pieced together to suit increasingly flexible and fluid cultural norms, Atkinson (2011) details how power can be produced in an aggregate form across and within social settings. For if one accepts that late modern Western societies are characterized by increasingly levels of contextual discontinuity, and that traditional social routines are of decreasing relevance as guides to direct social interactions, the need to reflexively consider one's performances of self becomes imperative (Adkins, 2002; Archer, 2003, 2007; Atkinson, 2011; Matthews, 2014). Following such logic, it is possible to understand certain men's continued domination of society as carved out through their ability to read and effectively perform appropriate social scripts rather than as determined via patriarchal social structures alone. Thinking back to the previous discussion of inequality at work, we can see this conception of men's power neatly fits with the flexibility and fluidity that characterizes the structure of organizations and many people's careers in contemporary Western society.

Yet, Atkinson's (2011) analysis, although replete with implicit empirical references, does not systematically attend to the continued place of social structures within the recreation of men's power. As Kondo (1990) demonstrates, the crafting of selves at work takes place in multiple and gendered contexts of power. In particular, Atkinson's thesis does not sufficiently acknowledge that certain groups of men, due to existing social and cultural privileges, are more able than others to claim power.
His theoretical underpinnings, which owe much to the reflexive modernity thesis (Beck et al., 1994), leans towards a conception of certain powerful men as released from the social structures that might normally constrain and enable their agentic engagement in social life. This structuring of action is the material and ideological legacy of patriarchy that MacInnes (1998) describes.

It is possible then to conceptualize the hegemony of men (Hearn, 2004) as not simply the product of unfettered appropriation of cultural scripts, but as residing in the ability to stitch the ideological and material legacy of patriarchy into social interactions through reflexive and often improvised social agency. So while Atkinson (2011) details rich empirical narratives about the winners and losers of late modernity, it is possible to broaden his theoretical analysis by exploring the structural constrains and enablements that are fundamental to understanding the recreation of men's power. That, for example, despite the breakdown of patriarchy as a more-or-less given pattern for the organization of society, it is still possible to see the legacy of this arrangement privileges white, educated, physically able, middle-class men through (1) their access to powerful social scripts at work and (2) the opportunity to develop the reflexive skills required to employ them correctly. Put simply, certain men might make their own power, but they do not make it as they please.

Archer's $(2003,2007)$ exploration of how reflexivity mediates social structure can be used as a means of bolstering Atkinson's discussion of men's power. Archer does not focus specifically on sex inequality in her analysis of social advancement and mobility, instead her focus is on detailing the inner conversations that are formative of social agents reflective engagement in social interactions. Building on Bhaskar's (1989: 26) argument that the "causal power of social forms [are] mediated through social agency", Archer $(2003,2007)$ demonstrates how social structures are reproduced or subverted through reflexive deliberation and subsequent agentic behaviours. When considering this in relation to men's power, the contextual discontinuity of late modern society might well have loosened the structural and discursive grip of patriarchy, yet it is only via social agents reflexive actions that this undermining of the traditional status quo is continued.

So while legislation is in place that theoretically provides women access to almost all careers and there is evidence of a decrease in the strength of cultural norms that can serve to gender specific jobs, such shifts towards equality ultimately continue to lie in the actions of women and men. Archer's (2003, 2007) attention to social structure within an analysis of reflexivity and agency provides a point of focus in this article; one which helps to shed light on one part of the social structuring of gender inequality, that is, the manner in which certain men reflexively understood their place within the systematically undermined, yet in some ways still advantageous, legacy of patriarchy. Within this study, I argue that the structural legacy of patriarchy can be mediated through men's ability to present performances of self that allowed them to take advantage of social enablements while also negotiating and circumventing social constraints placed upon their attempt to gain social advancement and power. This, I will argue, is how we can understand that men and narratives about them might change in apparently progressive ways, but the unequal power relations of gender stay broadly the same. Before developing this discussion, I will outline my methodological approach.

\section{Method-concatenated exploration}

The data presented in this article came from a variety of studies via a rather convoluted process. The most accurate way of describing this process is using Stebbins' (2006: 464) notion of concatenated exploration, in which, "open-ended studies are all linked together, as it were, in a chain leading to cumulative, 
often formal, grounded theory". While there has certainly been a great deal of empirically led theorizing, the reference to grounded theory could be somewhat misleading. Rather, this project has been developing over the last 5 years, as my thinking about and understanding of social theory has also developed. In that regard, there has been a repeated "to and fro" between theory and evidence. What Maguire (1988: 188) following Elias (1956) calls "uninterrupted two-way traffic" was for me a repeatedly interrupted, often stalling but ultimately productive process of thinking about and exploring the manner in which we can understand contemporary Western examples of men's power.

I "learned the ropes" of research as I moved from PhD student, to research associate, to lecturer working on various smaller projects to, principle investigator. As my skills as a researcher improved so did my analysis, as Stebbins (2006: 486) describes, "with concatenation of field studies, there is a tendency for exploration to be increasingly channelled by the developing conceptual framework". Each research project provided opportunities to read and think about social theory in relation to a novel empirical setting. Eventually, this process enabled me to reconsider earlier data through a developing theoretical lens.

In Matthews $(2014,2016)$, I explore the way in which men in a boxing club employed a pastiche arrangement of narratives about natural manhood to explain their enjoyment of ritual violence and the domination of the space inside and around the boxing ring. The theorizing for these articles was developed some time after the data were collected and came after I had spent a lot of time reading gender theory for a project on men's health (Matthews, 2015; Gough et al., 2016). As my theoretical understanding of men became more nuanced I was able to go back to my field notes and interviews with a fresh conceptual map that resonated with my participants thoughts and experiences. This resonance is key, for without this it is easy to see how the men whose personal lives I explored could become "automated figures who are pushed and pulled according to whatever theoretical scheme animates the tale" (Van Maanen, 1988: 131). Such a process would represent a disjuncture between the twoway traffic of theory and evidence whereby an abstract theoretical argument would override empirical data. Importantly, the data were able to provide the basis upon which certain theoretical claims could be evidenced, explored and refined. Yet, the dataset (like all datasets) had limitations, as such, key dimensions of how these men were able to use this reflexive pastiche arrangement of ideas were left underdeveloped.

As I conducted different studies, various opportunities presented themselves to collect data that could contribute to exploring these ideas. At times this happened consciously; I would specifically ask questions to probe men's situational reflections on social life. And other times I would look over data and find "nuggets" that linked to my analysis. I make no apologies for pulling these "bits" of data together into a bricolage as a means of thinking through the theoretical concerns I explore in this article. While some may find such a method unorthodox, it has allowed me insight into the manner in which a selection of men thought about and attempted to create social influence and power.

After a number of years of collecting data in this manner, and continuing to read and develop my theoretical understanding of power, I conducted a set of interviews specifically aimed at exploring the notion of pastiche hegemony. These interviews often took place in an ad hoc fashion when opportunities presented themselves to speak to men who appeared to embody, appreciate and understand elements of the presentation of self that Atkinson (2011) describes. Building on these interviews I asked the men I spoke to if they knew others who also considered social life in a similar manner. This generated a snowball sample and enabled me to tap into loosely connected groups of men who shared some key characteristics. Within these interviews I presented myself as far as possible as "one of them", as a man savvy to the world and able to understand their ways of being. This was not a static representation of self, and where possible I used my white, able-bodied, 30-something, middle-classness in a flexible manner to help develop trusting, though temporary, dialogues with these men. While it is hard to know with any degree of accuracy how I was perceived by them, I think that in presenting myself in this manner I was allowed "back stage" (Goffman, 1959) access to parts of their performances and techniques for achieving power.

This is a highly selective sample that was in part sought out so that theoretical and empirical issues around the recreation of men's power could be explored. As such, the findings offer a relatively unique exploration of certain men's lives, rather than generalizable conclusions about all men or manhood as social practice or cultural discourse. This is necessarily a partial picture. Indeed, my way into exploring the social structures that shape these men's lives and power chances is through their eyes. I rely on their reading of their social settings to construct my analysis. While no claims are made based on this data to know objectively the structures that frame their lives, it is important that the reader considers and understands the limitations of the study. That said, the data presented here allow insight into the potential for these men to produce power through strategic, reflexive readings of their social worlds, and, as such, is useful for thinking through the pastiche hegemony of men.

\section{Sample-the reflexive winners}

In total I interviewed 25 men specifically for this project, and I have drawn data from four different studies to include another 30 men. The interviews varied from 10 minutes to 2 hours and were sometimes one off meetings and at other times part of wider ethnographic studies. The 55 men in this study can be considered the "reflexive winners" (Lash, 1994) of late modernity who were able to frame themselves in various ways which they considered enabled them to be successful at work. All the men had carved out careers in what can reasonably be considered respectable, professional and/or high-status areas of employment; doctors, lawyers, managers, senior designers and business owners. Importantly, they also self-reported as having either successful or reasonably successful careers. While such measures are highlight-subjective, they serve the purpose here of highlighting how these men situated themselves against culturally normative ideas of success at work and by extension for many of the men in life more broadly.

The men were aged between 34 and 42 with a mean age of 37 . They identified as either English or British. The majority also identified as white, with four self-defining as black and four as mixed raced. Five men defined themselves as gay, four bisexual and the remainder consider themselves to be straight. When asked to define their class they all described themselves as either working (20) or middle-class (35), but the majority also noted how such categories did not neatly fit with their biographies. While their life stories certainly contained the ups and downs that one might expect, they all confidently described how they had come to find success at work and often more broadly in family and social settings. It is important to be realistic about the reliability of such claims considering the subjective and singular viewpoint that these interviews offer. Notwithstanding this caveat, the following sections explore how these men understood their agentic place in producing this success.

\section{Mapping out the analysis}

To arrive at the key thesis of this article I follow a slightly indirect path. A necessary step before being able to explore the specifics of 
how these men considered themselves capable of producing power at work is to unpack their understanding of the social worlds in which they existed. It is through such interpretations that we begin to understand their personal modus vivendi and it is here that we start to see the basis of how they produce social power; in their willingness to read, align with and pragmatically employ their knowledge of changes in the structure of society. Initially I focus on how they read society more broadly, and then explore their understandings of changes in patterns of gender relations. These two sections allow for insight into how the men were able to arrange social scripts in a pastiche manner to produce situational social power, an idea I explore in the final section before offering some concluding remarks.

\section{Embracing contextual discontinuity-"play the game"}

Changes associated with late modernity to the structural arrangement of many careers and working environments have partially undermined traditional power chances. Yet, new means of gaining and maintaining power accompany such social shifts. The ability to read this process can then be considered as a formative step in attempting to access the opportunities and rewards that are embedded in changing patterns of society. The men I spoke to understood this logic in relation to their working lives. There were two broad ideas that underpinned their thoughts: (1) that the social worlds they existed in were changing rapidly and (2) that awareness of such shifts and a willingness to react to them was essential for social advancement.

When asked what was producing such change, the men tentatively suggested a variety of overlapping reasons, including technology, globalization, capitalism, feminist-inspired politics, overpopulation and population-wide increases in education. Regardless of what they considered to be the mechanisms, the men were resolute in their belief that the traditional ways of doing things were increasingly redundant. They had mixed feelings about such changes, yet they pragmatically accepted the need to understand how this process affected their lives. They embraced the contextual discontinuity in which they were embedded and, as Archer (2003, 2007) and Atkinson (2011) demonstrate, this meant that they were well placed to grasp at power chances that might be presented to them.

While their subjective assessment of the structure of society can clearly be inaccurate, their reading of social settings guided their reflexive deliberations about what courses of action would tend towards producing positive personal outcomes. Exploring the men's awareness of their social settings is then a basis from where we can start to understand how they might be able to gain and maintain social power. Take Spencer ${ }^{1}$ and Gary $^{2}$ who told me the following:

Spencer: I learned very quickly that the skills I had from my first education were not going to be enough you know. To be honest, I didn't get much from my schooling anyway, it wasn't a good school. My first proper manager, I mean someone who knew how to manage, I learned loads from him. I remember him saying, and this is years ago right, he said, "you've got to think differently to all us lot," meaning the older people at work, "because it's all gonna change." It was already changing 'cus of technology so its not like he was an oracle or anything, he just saw what was happening, but that stuck with me.

Gary: I've mentioned this to you before, but people have to play the game. Some people are just so stubborn and stuck in their ways that they don't see the rules of the game of changed. At work it's full of the old school mob, they can still get by on a building site see, but they don't get on, that's the difference. I know I was pushed up 'cus they know I'm savvy to how things have moved on; health and safety, work legislation, cash-in-hand stuff, fairness, equality all that. That's the game now, it's not like it was, so what you gonna do fight it? Stick your 'ead in the sand? Or work the system!

For Gary the notion of "playing the game" and playing it well was synonymous with the process of learning how to read, reflexively consider, and act accordingly to, structural and cultural changes. For him and the other men the ability to understand the rules of the new "social game" was an important part of their lives at work and beyond. So while we can see that Atkinson (2011), building on Goffman (1959), describes techniques for achieving power through the reflexive presentation of appropriate performances of self, at the foundation of this process is the ability to effectively read and situate oneself within the changing social structures that provide the scripts for such performances.

While the men certainly did not welcome all the social changes that they found themselves surrounded by, they pragmatically accepted them and actively looked for ways in which they could be advantageous to their careers. Archer $(2003,2007)$ discusses a similar process and argues that embracing such contextual discontinuity is a key dimension of social advancement in late modernity. All the men in this study adopted this broad stance of pragmatic acceptance. Indeed, it provided them with an ideological outlook on life that appeared to predispose them to exploit opportunities and mediate threats to their social power. Of particular focus in this article is the manner in which this process underwrote their ability to produce pastiche hegemony through their reflexive "playing of the game". Specifically, they believed this could be achieved via the situational performance of renditions of manhood that resonated with the need to appear anti-sexist, antihomophonic, anti-racist and overtly in favour of equality, while at other times drawing on the legacy of patriarchy to grasp at social power. I will develop this claim in the following section.

\section{The discontinuity of men's power-"swim with the current"} The contextual discontinuity produced via changes in the structure of late modern society has a specific gendered dimension (Kondo, 1990; Adkins, 2002; Atkinson, 2011). The men could read elements of this process and all thought that it effected what it meant to be a man and the ways in which men could be powerful. They understood that society was no longer organized along simplistic patriarchal lines whereby men could simply assume power over women in an unproblematic manner. Indeed, they had a sense for MacInnes' (1998) claim that the legacy of patriarchy was being systematically undermined. $\operatorname{Dan}^{3}$ neatly captured this:

Dan: There's no space anymore for cavemen. Well, in the scrapheap perhaps. But things don't just suddenly completely not matter, it doesn't work like that. What I mean is, we all know you can't be a dick head bloke anymore and get away with it, but that doesn't mean it doesn't still happen, people don't just change like that [clicks fingers]. So there's this need for people to change but not everyone can, the key is that that means you look good because you can change with the times, know what I mean?

Christopher: Not quite ...

Dan: Basically, those who don't keep up to date with stuff make us, the people who do, look good. But only because we understand how to behave now.

Christopher: Have you an example?

Dan: Like I said, the cavemen idea. There's no room for men being like that anymore, guys have to realise those times are behind us. 
Such discussions over the notion of "out-dated" performances and narrations of manhood were a reoccurring theme. The men were keenly aware of social, cultural and political shifts that undermined patriarchy and, importantly, this shaped the manner in which they socially interacted with others.

Through a personal ontology they understood, like Fraser (1989), that patriarchy has a specific historical formation and the contemporary narratives about gender had constrained the ways in which they could grasp at social power. They altered their behaviours accordingly to ensure that they did not get cast on to the proverbial scrapheap. Old ideas about man at work were out, new ideas were in, Spencer described how this changed his working environment:

Christopher: So you've told me how things have changed at work for traditional men, so how do you deal with that?

Spencer: Well it's pretty easy, just don't be a traditional man. It's far easier to swim with the current than against it, especially when it's so bloody easy. The old style dodgy dealing wide boy isn't going to get you anywhere and who want's to live like that anyway. It's far easier to do things by the book properly. No one needs an aggressive goon to go and collect rent anymore, we work in a polite, caring and professional manner. It's just a better way of being. (my emphasis)

Importantly, the men did not simply change their presentation of self to fit a static narration of acceptable late modern manhood. The changing and fluid nature of their social settings did not allow for such a simple conception of their social performances. Rather, they reflexively deliberated about how they should behave in different contexts. And it is within this situational presentation of self, which I develop in what follows, that we begin to understand how they could gain and maintain situational hegemony.

It is within this process that the increasingly undermined legacy of patriarchy is mediated through savvy social performances into situational and contextual power plays. Using Goffman's (1959) dramaturgical analogue, the men I spoke to believed that their ability to locate themselves within different "social stages", to effectively "know their lines" and to improvise was an important part of their successes in life. Take what Julian ${ }^{4}$ told me as an example:

There's a lot expected of men nowadays and it's impossible to actually be all those things. But you can certainly give it a go and at least look like it. You've got to be fair to women but also take control in relationships and during sex. It just means you can't be stuck in one way or another, you've got to be flexible and quickly figure out the way to act naturally. It's like being a kid and growing up to figure out what's appropriate in different situations but now we have to do it all the time as society keeps changing. My old man didn't need to worry about any of this, he just lived his life the same way he'd learned when he was 20 .

So while the men could see the importance of swimming with changing social currents, they also understood that this process was uneven and context dependent. ${ }^{5}$ As such, there was no room for a static presentation of self due to the proliferating and often times paradoxical demands that they believed are now placed on men.

Atkinson (2011) discusses how such contextual discontinuity sits at the foundation of discourses about the apparent "crisis of masculinity" and the unhappiness, depression and sense of desperation that can be experienced by men who fail to negotiate it effectively. In a similar way Archer $(2003,2007)$ describes the "fractured reflexives" that are unable to take control of their lives via a coherent reflection upon the social setting in which they find themselves. In many ways, the men I spoke to were the antithesis of such people. Importantly for them, their pragmatic acceptance and embracing of the changing social discourses about what it can mean to be a man provided cultural and social space where they could gain social advantage, influence and reward. Indeed, because the nature of what constituted a "real man" was thought to be less reliant on patriarchal social scripts, there was increased space for narrations of manhood to be carved out in contextually specific forms so as to unlock social and cultural power. In effect, the systemic undermining of patriarchy enabled men who could read these processes and change accordingly to still activate the legacy of unequal social relations while also carving out new forms of social power through a pastiche arrangement of performances. Clearly then, as Segal (1993) points out, the problem of men's power shifts.

\section{The pastiche use of enabling social scripts-"like putting different hats on"}

Atkinson (2011) uses the idea of a "chameleonlike" presentation of self to unpack contemporary understandings of men's power. Thinking with this idea we can understand how the chameleon is effective when it blends into its background; this is both a product of its effective reading of its surrounds and its ability to situate itself within them. The "social chameleons" that I spoke to described effectively reading their social world and using this information to craft performances of self. They thought that this process produced more believable and polished performances and could avoid being read as what Goffman (1959: 252) calls a "harried fabricator of impressions". The following quote from Dan illustrates this point:

I can portray myself as a different man in different places. It's not hard, it just means you need to be on the ball and not get caught out. In the end, if you try too hard you'll get caught out, so the way you act needs to be based on reality, in the real you, but you can emphasis bits and de-emphasis others. I'll be a bit macho at times at work, but then caring with the kids. I sometimes think it's like putting different hats on; what man hat have I got on today? (my emphasis)

This process opens up avenues for the crafting of selves using a diverse array of cultural narratives and with these came new ways of gaining cultural influence and power. While this was not an individualistic free-for-all, whereby the men could draw on any and all scripts to shape social performances, they were able to represent themselves in a variety of ways. Importantly though, if we take the men's reading of their actions at face value, the material and ideological legacy of patriarchy when reflexively employed in a savvy manner enabled them to grasp powerful narratives associated with work and this process reified this increasingly undermined legacy in albeit localized forms.

This legacy offered the men contingent access to social power. The residue of the structural link between men and work, although increasingly undermined, could, in the right conditions, still be reified by these men. Importantly, their personal reflections upon their place within the changing structure of late modern society enabled this strategic mediation of social power. As an example, Rick, ${ }^{6}$ echoing Gary's earlier comments about playing the social game, told me the following:

Christopher: Can you tell me about how you influence people at work?

Rick: It's not like I set out at the start of the day with a master plot in my head about what I'm gonna say to this 
person or to that [person]. But there's ways to act in certain situations and as long as you know that you might as well play the cards you are dealt as well as possible right?

Christopher: Can you give me an example?

Rick: I've told you this one before, but like with the nurses at work, there's some who're old enough to be my mum and there's others that are younger than me, its obvious; respect and kindness to the older ones and a bit of 'treat them mean keep them keen' for the younger ones. I'll get Christmas cards and chocolates for the older ones, but the younger ones can handle a bit more banter and they love it, it's like flirting but without going to far.

A Goffmanesque performance of self is writ large in this extract, importantly though, Rick appears to not only know the lines of these social scripts but also the parameters of the stage and used this knowledge, so he believed, to gain influence at work. Clearly contriving different presentations of self runs the risk of being "caught out", yet, Rick's confident reading of his social context lead him to believe in his ability to manage different impressions in different settings.

If taken at face value, Rick's savvy reading of his working environment can be understood as an element of his ability to access potential powerful social scripts in various settings. George $^{f}$ described a similar process within and outside of work:

I go to these [weight management] sessions with some girls from work. I manage some of these women but I really need to lose some timber so I thought sod it, if it helps me get in shape I'll just have to do it. So when I went to this session, I knew it would be all women right, and imagine if I went in and gave it the big one like someone might do, they'd send me packing. Instead I went cap in hand, playing a bit sheepish, well I was a bit nervous anyway, but there's no harm playing it up right? And they all welcomed me in, like its kind of validated their programme 'cus a man's attending. So then I thought I have to be careful here 'cus I need to be strong at work but in these sessions you're kind of vulnerable especially because is just me on my own. But I just show a different side to myself, you know, I take my tie off, I don't act like the boss, I talk to them on a different level when I'm there. They get it; back at work we don't discuss it much, but, I know they've seen a different side to me now and the best thing is because of that I have closer relationships with them at work but I can still maintain quite a strong management style.

In a similar manner, $\mathrm{Ben}^{8}$ described the management styles that were available to him as long as he could maintain a certain public persona:

Christopher: Do you think it's easier for men to still be managers at work, even after all the equality stuff we have discussed?

Ben: I've had this conversation with people at work, the thing is it's harsh because I think you are right, women have to worry about stuff I won't need to worry about. No one's gonna call me a bitch if I'm hard on people. Basically, as long as I'm on the ball with how I go about it I can still do all the classic management stuff, the stuff they all say we shouldn't be doing any more, I just have to be strategic about how people think about me, its just branding.

Christopher: You consider yourself like a brand you work on?

Ben: Basic PR right, manage your image and you can get away this stuff. So as long as people think I'm alright, calm, fair etc. I don't really have to actually do any of that stuff. I'm not a dick but I get myself a pass for when I do something that's a bit, shall we say, old school style.
So for Ben "being hard on people" while still requiring some level of strategic management was less likely to cause problems that it might for a female colleague. Rick, George, Ben and the other men believed they could gain influence and control in social interactions at work if they simply considered their social context and based on this knowledge act in a strategic manner. As Julian described it, by putting on different "man hats" in different contexts they could present a version of themselves that they believed enabled them to produce influence and power in various settings.

While society was changing around them, they believed that as long as they remained savvy to such contextual shifts, they could still employ social scripts connected to work that have traditionally been more associated with powerful and patriarchal men. The key here was their ability to contingently employ these enablements through performances of self, rather than simply identifying as a certain "type" of men in all social settings. As such, it is possible to see the potential for these men to circumvented changes to the structure of society that systematically undermine men's power and still access social privileges embedded in the legacy of patriarchy, while also accessing new forms of cultural and interactional power by framing themselves as progressive, fair and equitable. They believed that they could use such social interactions to help them achieve success and power at work. While it is impossible to know from these singular and subjective viewpoints how successful these behaviours were, it is possible to understand that through such reflexive and strategic action they had the potential to earn a pastiche hegemony "bit-by-bit, metre-by-metre, interaction-by-interaction" (Atkinson, 2011: 42).

\section{Concluding remarks}

No claims have been made here to "prove" that the men in this study were socially hegemonic in any simplistic sense. Rather, the data I have presented have been used to help think through $a$ way in which we can theorize how men and narrative about them might change while power inequalities can be recast and recreated. What I have tried to achieve with this article is an understanding of the radically contextual nature of power that is mediated through social agents' reflexive understanding of the changing shape of late modern society.

It might be tempting to interpret these men as sexist, misogynists who are setting out to maintain in some form or another an archaic patriarchal society. Such an understanding certainly did not match the way the men framed their actions. Rather, they believed they were simply "playing the game" to take advantage of opportunities for their own personal advancement. Importantly, such an innocent appraisal of the consequences of their social actions would void the ways in which these reflexive practices mediated social power and could reconfirm inequality. For as Archer argues:

Despite the fact that practises of individual agents are not intentionally geared towards producing societal effects, nonetheless these are the external outcomes of the exercise of their personal powers. In general, they are small in scale and undramatic, but their microscopic nature does not deprive them of cumulative significance. (Archer, 2003: 356)

So while it is important to appreciate that these men do not set out some sort of plan to maintain patriarchy, we certainly can understand that the reproduction of social inequality at work, and in society more broadly, can be effectively theorized as in part a product of their reflexive actions. Moreover, I would argue that in 
drawing out a sensitivity to such performances as a reification of the ideological and material legacy of patriarchy, we are better placed to capture the pastiche nature of men's power in late modernity. In reading their social settings to help craft appropriate selves (Kondo, 1990) these men believed they were able to gain influence and control at work, as such, unpacking this process helps us to explore the continuing "hegemony of men" (Hearn, 2004) within social relations that appear to undermine patriarchy.

Archer (2003: 343) describes "fractured reflexives" that experience "something akin to paralysis of their personal powers" due to the inability to effectively consider their place within society and act in a manner that would produce a coherent strategy towards taking control of their lives. The data from this study suggests that these men are the polar opposite. They believed that by effectively reading social settings that undermine previous incarnations of patriarchy, they could reflexively plot performances of self that helped them to (1) mediate social constrains and (2) access social enablements. At the foundation of this process was their willingness to acknowledge that society was changing and that, as such, traditional ways of being might be increasingly undermined. This was based on their reflexive reading of their social settings, which, through the material and ideological legacy of patriarchy, still provided them with contextual and situational opportunities to craft performances of self to gain power as men at work.

In addition, it appears that the undermining of patriarchal social relationships has broadened narratives about what a "real man" can be and given these men access to social influence and power via a diverse means of presenting themselves in social settings. Yet, as Segal (2007: 245) argues, "men may be permitted greater flexibility today, but it may not be easy for all men to adopt such flexibility". So while Atkinson (2011) neatly theorizes the pastiche power that can come from such flexibility, I have explored now this process might be accessed by certain men through their ability to reflexively read and act accordingly to their social contexts. It is within such an analysis that we can unpack how men might change but the hegemony of man can stay broadly the same. Indeed, it appears from this data that the loosening of traditional structures of gender is itself a structured process that confers power on those who are best situated to access the opportunities and limit the constraints that it presents. Exploring the structuring of this process enables an understanding of the manner in which men's power is recast in spaces that are apparently equitable. It appears then that patriarchy might be dead, yet a more diffuse and potentially insidious pastiche hegemony of men might live on if the material and ideological legacy of the "rule of the father" can be reified through the reflexive and situationally contingent power plays of certain men.

\section{Notes}

1 A 39-year-old, white, straight, property manager, from Yorkshire. He had worked in a variety of setting before deciding to start a company with a friend who also worked in a similar area.

2 A 35-year-old, white, straight, building site manager, from the East Midlands. He had worked his way up to this position after starting as an apprentice.

3 A 35-year-old, black, straight, teacher, from the South East, who believed he was on course to be a head teacher before he was 40 .

4 A 36-year-old, white, straight, pharmacist from the East Midlands, he managed the pharmacy where he worked.

5 See Matthews (2016) for an example of how we can theorize social spaces that remain resistant to change.

6 A 34-year-old, white, straight, doctor, who worked in a big hospital in the North East of England.

7 A 42-year-old, straight, white, council manager from the Yorkshire.

8 A 37-year-old, gay, senior graphic designer, from the East Midlands, who managed a team of between eight and ten people.

\section{References}

Acker J (1990) Hierarchies, jobs, bodies: A theory of gendered organizations. Gender and Society; 4 (2): 139-158.

Adkins L (1995) Gendered Work: Sexuality, Family and the Labour Market. Open University Press: Buckingham, UK.

Adkins L (2002) Revisions: Gender and Sexuality in Late Modernity. McGrew-Hill: New York.

Archer MS (2003) Structure, Agency and Internal Conversation. Cambridge University Press: Cambridge, UK.

Archer MS (2007) Making Our Wax through the World-Human Reflexivity and Social Mobility. Cambridge University Press: Cambridge, UK.

Atkinson M (2011) Deconstructing Men and Masculinities. Oxford University Press: Oxford.

Avery DR, McKay PF and Wilson DC (2008) Demographic similarity affects the prevalence of perceived employment discrimination. Journal of Applied Psychology; 93 (2): 235-249.

Bauman Z (1996) From pilgrim to tourist-Or a short history of identity. In: Hall S and Du Gay P (eds). Questions of Cultural Identity. Sage: London.

Beck U, Giddens A and Lash S (1994) Reflexive Modernization-Politics, Tradition and Aesthetics in the Modern Social Order. Polity Press: Cambridge, UK.

Benard S and Correll SJ (2010) Normative discrimination and the motherhood penalty. Gender and Society; 24 (5): 616-646.

Bhaskar R (1989) The Possibility of Naturalism. Harvester Wheatsheaf: Hamel Hempstead, UK.

Blau FD, Briton MC and Grusky DB (2006) The Declining Significance of Gender? Russell Sage Foundation: New York.

Brody C and Rubin BA (2011) Generational differences in the effects of insecurity, restructured workplace temporalities, and technology on organizational Loyalty. Sociological Spectrum; 31 (2): 163-192.

Brumley KM (2014) The gendered ideal worker narrative: Professional women's and men's work experiences in the new economy at a Mexican company. Gender \& Society; 28 (6): 799-823.

Burstein P (1989) Attacking sex discrimination in the labour market: A study in law and politics. Social Forces; 67 (3): 641-665.

Burton C (1991) The Promise and the Price. Allen and Unwin: Sydney, Australia.

Cockburn C (1983) Brothers: Male Behaviour and Technological Change. Pluto Press: London.

Collinson DL (1988) Engineering humour: Masculinity, joking and conflict in shop floor relations. Organization Studies; 1 (3): 58-76.

Collinson DL (1992) Managing the Shop Floor: Subjectivity, Masculinity and Workplace Culture. Walter De Gruyter: Berlin.

Collinson D and Hearn J (1996) Men as Managers, Managers as Men: Critical Perspectives on Men, Masculinities and Management. Sage: London.

Dalton N (1959) Men who manage. Administrative Science Quarterly; 5 (2): 323-326.

DeCoster S, Estes SB and Muller WC (1999) Routine activities and sexual harassment in the workplace. Work and Occupations; 26 (1): 21-49.

Elias N (1956) Problems of involvement and detachment. British Journal of Sociology; 7: 226-252.

England P (2010) The gender revolution: Uneven and stalled. Gender and Society; 24 (2): 149-166.

Fraser N (1989) Unruly Practices-Power, Discourse and Gender in Contemporary Social Theory. Polity: Cambridge, UK.

Goffman E (1959) The Presentation of Self in Everyday Life. Anchor: New York.

Goldin G and Rouse C (2000) Orchestrating impartiality: The impact of "blind" auditions on female musicians. American Economic Review; 90 (4): 715-741.

Gorman EH (2005) Gender stereotypes, same-gender preferences, and organizational variation in the hiring of women: Evidence from law firms. American Sociological Review; 70 (4): 702-728.

Gough B, Seymour-Smith S and Matthews CR (2016) Body dissatisfaction, appearance investment and wellbeing: How older obese men orient to "aesthetic health". Psychology of Men and Masculinity; 17 (1): 84-91.

Hall A, Hockey J and Robinson V (2007) Occupational cultures and the embodiment of masculinity: Hairdressing, estate agency and fighting. Gender, Work and Organization; 14 (6): 534-551.

Hearn J (1992) Men in the Public Eye: The Construction and Deconstruction of Public Men and Public Patriachies. Routledge: London.

Hearn J (2004) From hegemonic masculinity to the hegemony of men. Feminist Theory; 5 (1): 49-72.

Jameson F (1991) Postmodernism, or, the Cultural Logic of Late Capitalism. Duke University Press: Durham, NC.

Kelly EL, Ammons SK, Chermack K and Moan P (2010) Gendered challenge, gendered response-Confronting the ideal worker norm in a white-collar organization. Gender and Society; 24 (3): 281-303.

Kondo DK (1990) Crafting Selves-Power, Gender, and Discourses of Identity in a Japanese Workplace. The University of Chicago Press: Chicago, IL.

Lash S (1994) Expert-systems or situated interpretation? Culture and institutions in disorganized capitalism. In: Beck U, Giddens A and Lash S (eds). Reflexive Modernization-Politics, Tradition and Aesthetics in the Modern Social Order. Polity Press: Cambridge, UK, pp 198-215 
MacInnes J (1998) The End of Masculinity. Open University Press: Buckingham, UK.

Maguire JA (1988) Doing figurational sociology: Some preliminary observations on methodological issues and sensitizing concepts. Leisure Studies; 7 (2): 187-193.

Matthews CR (2014) Biology ideology and pastiche hegemony. Men and Masculinities; 17 (2): 99-119.

Matthews CR (2015) The appropriation of hegemonic masculinity within selected research on men's health. International Journal for Masculinity Studies; 11 (1): 3-18.

Matthews CR (2016) The tyranny of the male preserve. Gender and Society; 30 (2): 312-333.

McDowell L (1997) Capital Culture: Gender at Work in the City. Blackwell: Oxford.

Morgan D (1992) Discovering Men. Routledge: London.

Moss Kanter R (1975) Women and the structure of organizations: Explorations in theory and behavior. Sociological Inquiry; 45 (2-3): 34-75.

Olson GA and Becker BE (1983) Sex discrimination in the promotion process. Industrial and Labour Relations Review; 36 (4): 624-641.

Prokos A and Padavic I (2002) There oughtta be a law against bitches': Masculinity lessons in police academy. Gender Work and Society; 9 (4): 441-459.

Reskin BF (1988) Bringing the men back in: Sex differentiation and the devaluation of women's work. Gender and Society; 2 (1): 58-81.

Ridgeway CL and England P (2007) Sociological Approaches to Sex Discrimination in Employment. Blackwell: Oxford.

Savage M (1987) The Dynamics of Working Class Politics. Cambridge University Press: Cambridge, UK.

Segal L (1993) Changing men: Masculinities in context. Theory and Society; 22 (5): 675-696.

Segal L (2007) Slow Motion-Changing Masculinities, Changing Men, 3rd edn., Palgrave Macmillian: London.

Stebbins RA (2006) Concatenated exploration - aiding theoretic memory by planning well for the future. Journal of Contemporary Ethnography; 35 (4): 483-494.

Strober MH, Arnold CL (1987) Integrated circuits/segregated labour: Women in computer-related occupations and high-end industries. In: Hartmann H (ed). Computer Chips and Paper Clips: Technology and Women's Employment. National Academy Press: Washington DC.

Van Maanen J (1988) Tales From the Field: On Writing Ethnography. University of Chicago Press: Chicago, IL.
Walby S (1986) Patriarchy at Work. Polity Press: Cambridge, UK.

Whyte WH (1956) The Organisation Man. Simon and Schuster, University of Pennsylvania Press: Pennsylvania, PA.

Williams CL, Muller C and Kilanski K (2012) Gendered organisations in the new economy. Gender and Society; 26 (4): 549-573.

Willis P (1977) Learning to Labour. Columbia University Press: Columbia, SC. Witz A (1992) Professions and Patriarchy. Routledge: London.

\section{Data Availability}

Data sharing is not applicable to this article, as no datasets were generated or analysed during the current study.

\section{Acknowledgements}

The author would like to thank Kath Woodward, Michael Atkinson, Joseph Maguire and Alex Channon, whose critical comments regarding the ideas presented in this work have given the author's analysis a much needed sharpening. Thanks also due to the men who have given up their time to speak to the author so openly about their lives.

\section{Additional Information}

Competing interests: The author declares no competing financial interests.

Reprints and permission information is available at http://www.palgrave-journals.com/ pal/authors/rights_and_permissions.html

How to cite this article: Matthews CR (2016) Exploring the pastiche hegemony of men Palgrave Communications. 2:16022 doi: 10.1057/palcomms.2016.22.

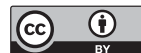

This work is licensed under a Creative Commons Attribution 4.0 International License. The images or other third party material in this article are included in the article's Creative Commons license, unless indicated otherwise in the credit line; if the material is not included under the Creative Commons license, users will need to obtain permission from the license holder to reproduce the material. To view a copy of this license, visit http://creativecommons.org/licenses/by/4.0/ 